\title{
Rape culture in Classical Athens?
}

\author{
Sotiria Rita Koutsopetrou-Møller
}

\begin{abstract}
Classical Athens had a culture of widespread sexual violence, where different forms of sexual misconduct were embedded in the normative framework. Numerous products of the city's 'popular culture', such as mythology, literature and art, propagated the normalcy of rape. A large body of modern scholarship has correlated this frequency with the particular Athenian bistorical context during the Cassical period, underlining that ancient Athenians followed different standards and guidelines than we do for the evaluation of sexual behaviour. This article demonstrates that in Classical Athens the repeated representations of rape in literature and art were means to preserve the fundamental principles of the established male order. The power structure of the Classical Athenian polis fostered attitudes that remind us of the modern concept of 'rape culture'. This concept, developed by feminist scholars to describe modern realities, reveals how societies can use culture to downgrade the moral wrongness of rape. Rape culture' will be used in this article as a model, or analytical tool, to reinterpret the Classical literary evidence on Athenian attitudes towards sexual assault. I will argue that this model makes better sense of the evidence than the now prevalent relativistic interpretation.
\end{abstract}

Keywords: Classical Athens, women, rape, rape culture, model

\section{Method}

Rape culture is the term used to describe environments where rape is normalised and excused and refers to social practices that sympathise with the rapist while blaming the female victims for straying outside their 'proper' sphere of action. ${ }^{1}$ According to this definition, societies whose cultures fuel behaviours and beliefs that encourage, excuse or perpetuate acts of sexual violence against women should be viewed as societies with a rape culture. The first feminist scholar to raise this issue was Nancy Rabinowitz, who saw a reflection of this modern concept in Greek tragedy. ${ }^{2}$ Subsequently, other scholars have raised and discussed similar questions either by exploring the historical origins of the 'heroic rapist' in Greek mythology or by explaining the perpetuation of the ancient stereotypes via rape myths and alternative theories.

${ }^{1}$ See Burnett 2016.

${ }^{2}$ Rabinowitz 2011, 16.

3 Ross 2019; DioGuardi et al. 2019. 
While a direct connection of modern rape culture with Greek Antiquity is almost unprovable, this concept can become a useful test model for the Athenian attitudes towards rape. The use of rape myths as a research tool can provide a wider understanding of the complex relationship between popular culture and the legal treatment of rape in Classical Athens as well as offer an alternative investigation into the intersection between the emotions of ancient rape victims and the prevalent Athenian attitudes. An analogous method has been recommended before by Mieke Bal, who suggested an exploration of the phenomenon between the past and the present through the use of the word rape. ${ }^{4}$

Consequently, in this article, I will deviate from the theories of cultural relativism in an effort to explore whether Classical Athens can be reconstructed as a polis of 'rape culture'. Cultural relativists in gender studies share the principle that every society has specific meanings and values which should not be compared to those in other cultures. With reference to this cultural particularitysense, scholars such as Susan Lape and Edward Harris claim that a discussion of rape in the Athenian context is a logical fallacy drawn from a contemporary cultural and moral problem. ${ }^{5}$ Nevertheless, this position raises challenges in examining the past by 1) presupposing an unjustified disruption of the historical phenomenon of rape, and 2) impeding any sort of causal explanations, which is, in the final analysis, possible only by using the comparative method. ${ }^{6}$ Every effort of ours to comprehend the life and attitudes of another culture will always have as a point of reference meanings, values and norms of our own culture. ${ }^{7}$ These elements consist of our cognitive and cultural preconceptions and facilitate our understanding. Rather than rejecting them as inappropriate, I suggest that we should recognise them as integral parts of the responses we give to the questions we raise about the past.

Hence, great as the difference is between the ways the male-dominated community of Classical Athens understood and treated sexual assault and the ways our postfeminist society does, there are similarities between them that can support this experiment. The essential characteristics of the ideas about gender roles and sexual behaviour in Classical Athens bear a surprising resemblance to many modern rape myths, in the sense that Martha Burt defined them, namely as 'prejudicial, stereotyped, or false beliefs about rape, rape victims and rapists' - in creating a climate hostile to rape victims ${ }^{8}$. In the spirit of this approach, several cultural products that entertained and titillated the Athenian spectators by trivialising sexual assaults against women forged their understanding of gender relationships and implicitly shaped their reactions to gender violence. For example, in Menander's Epitrepontes, (line 1123), the old nurse, Sophrona,

\footnotetext{
${ }^{4}$ Rabinowitz 2011, 6 cites Bal 1994, 38.

${ }^{5}$ See Lape 2001, 85; Harris 2006, 331; Rabinowitz 2011, 6 also cites David Konstan 1994, 229.

${ }^{6}$ See Kocka 2003, 29-44.

${ }^{7}$ See Brown 1993, 192.

${ }^{8}$ Burt 1980, 217.
} 
conveys a rather fatalistic idea about rape when she responds to Smikrines, father of the girl, Pamphile, who gave birth to a child after being raped, that it is the nature of woman to become pregnant by any means even illegal ones, such as rape.

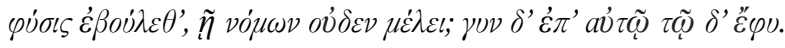

Nature wanted this, and she does not care for laws: but it is in the nature of woman to come in this condition. ${ }^{9}$

In Aristophanes' Lysistrata, (lines 160-164), first staged 411 BC, the dialogue between Calonice and Lysistrata discloses the frequency of marital rape, which is presented as a simple 'part of marital life' and tolerated by the Athenian spouses. This gives us a hint of the socio-cultural beliefs of this period regarding sexual behaviour. It establishes the invincibility of male lust as eternal law and naturalises the female submission to male coercion. The dialogue smartly embellishes marital sexual violence against women communicating the message that not only should it be expected, it should also seem, under normal circumstances, pleasant for women to sexually satisfy men:

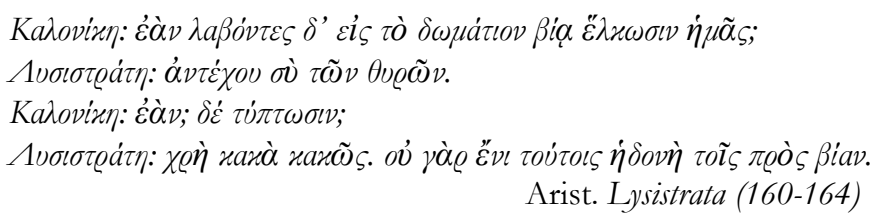

Calonice: If they catch us and drag us by force into the bedroom? Lysitrata: Hold onto the door.

Calonice: If they beat us? Lysitrata: You must yield in an unwilling way. It's not enjoyable for the men, when the women are forced. ${ }^{10}$

Finally, in Aristophanes' Birds (1253-1256) (414 BC) the sexual male threat against the goddess, Iris, displays how Athenian men intimidated women, believing that they had a right to their bodies:

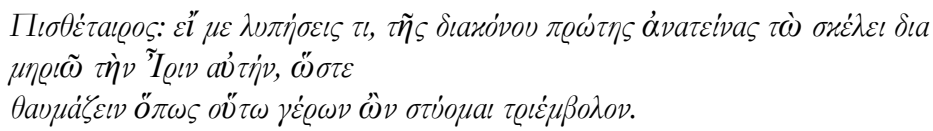

Pisthetaerus: As for you, his messenger, if you annoy me, I shall begin by getting between your thighs, and even though you are Iris, you will

\footnotetext{
9 Translation by the author.

10 Translation by the author.
} 
be surprised at the erection this old man can produce; it's three times as good as the ram on a ship's prow!11

The previous passages indicate why rape culture provides an interesting interpretative framework for delineating and decoding the various approaches to rape in Classical Athens. The similarity of the underlying ancient ideas to our modern rape myths offers a useful starting point for discussing the multiple depictions of female rape in Athenian popular culture and divulges the antithetical values that determined on the one side the legal treatment of female rape and on the other side the literary portrayal of it as a shocking human experience.

Hence, by taking into consideration the theoretical analysis of Hunter Gardner and Corina Martha Brunini-Cronin that Athenians could conceptualise rape as a traumatic experience for women, ${ }^{12} \mathrm{I}$ discuss the evidence from the Athenian plays of Euripides' Ion (411-412 BC), and Auge (around 408 BC), Aeschylus' Agamemnon (458 BC) and Menander's Epitrepontes, arguing that despite the historical particularity of Classical Athens, these playwrights perceived and portrayed the emotions of their raped heroines in ways that we can comprehend and describe today. On that account, we can assume that the Athenians consciously discerned between the shocking human experience of rape and the legal treatment of it for reasons lying in the existential need of the Athenian male governance to use women as reproductive objects at any cost. This comprehension rationalises the contradiction between the legal remedies of rape viewed as acts of violence or bybris 'outrage, insolence' always committed against the guardian of the woman victim and the representations of women's rape in the Athenian popular culture, which repeatedly depicted the true nature of the rape trauma.

In light of this, my article is divided into two thematic parts. In the first part, I concisely summarise how previous scholarship has treated the problem of semantics and how it evaluated the attitudes toward sexual violence against women in Ancient Greece. Subsequently, I briefly present my own thoughts on the issue maintaining why we should evaluate as rape sexual acts in Greek Antiquity that we understand as such. In the second part, I analyse the legal treatment of rape in Classical Athens exploring whether, and if so how, political aspirations affected the implementation of the law. Then, I refer to evidence from the above-mentioned literary sources where the dramatic performance of female rape deviated from the content of the Athenian law. Finally, by utilising the test model of rape culture, I demonstrate that the male system in Classical Athens wilfully undercut the traumatic impact of rape on its female survivors, espousing only attitudes that would keep patriarchy alive.

\footnotetext{
11 Translation by O’Neil 1938.

12 Gardner 2013, 121-122; Brunini-Cronin 2016, 81.
} 


\section{The Problems of Semantics and Evaluation}

The ancient Athenians lacked an exact match for the English word rape, albeit their popular culture included a plethora of rape narratives. Legal speeches, literary sources, philosophical texts and artistic portrayals refer to incidents of coerced sexual intercourse by using expressions connected either with violence (bia) or with outrage-insolence (bybris). ${ }^{13}$ Factors such as the circumstances surrounding the crime or the direct consequences of it determined the choice of the word used. For example, Plato in the Laws employed the verb biazomai

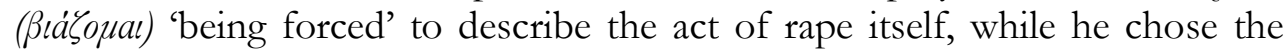
passive tense of bybrizein (í $\beta$ i $i \xi \varepsilon(v)$ 'to injure, outrage' for expressing what the victim suffered at the hands of the assailant. ${ }^{14}$ The question of semantics becomes more complicated because the Greek sources describe female sexual assaults in quite ambivalent ways. While rape was undoubtedly a serious crime according to Athenian law, literary sources do not always depict it as such.

In addressing the unusual situation, where a society was aware of a phenomenon without naming it, scholars explain this omission in the Greek language variously and evaluate the Athenian attitudes toward rape in contradictory ways. Edward Harris has strongly argued that 'rape is a nonexistent topic in ancient Greece' claiming that the term is anachronistic because it interprets the sources according to modern standards. ${ }^{15}$ Therefore, he suggests that 'we should stop using the word rape, but instead examine the Athenian attitudes towards sexual violence. ${ }^{16}$ Mary Lefkowitz also denies that the practice of rape existed in the Greek myths interpreting the unions of gods with mortal women as abductions or seductions. Her theoretical justification is based on the assumption that the Greeks considered these experiences with the Gods as pleasant for the human counterparts especially because their consequences, in terms of semi-divine offspring, were glorious both for them and their families. ${ }^{17}$ The joy of these encounters was portrayed in their idyllic descriptions, which were in accordance with the strict Greek morality as well as the female's predestined mission in this ancient society. ${ }^{18}$ Since Athenian women had no better alternatives than marriage and reproduction, a God's abduction or seduction was the happiest fate that could befall them. ${ }^{19}$ Lefkowitz adds that the Gods asked for consent before the encounters, making the opportunity of choice and human responsibility evident in these stories. ${ }^{20}$

\footnotetext{
13 See Cole 1984, 98-99 for a detailed account of expressions that denote rape.

14 Cohen 1991b, 175; Omitowoju 2002, 54.

${ }^{15}$ Harris 1997, 483; 2006, 305-306, 331.

16 Harris 2006, 306.

17 Lefkowitz 1993, 17.

18 Lefkowitz 1993, 21, 33.

${ }_{19}$ Lefkowitz 1993, 33.

${ }^{20}$ Lefkowitz 1993, 34-35. See also Karantza 2004, 29-45 who correlates rape with wedding and public rituals or other cultural and civic issues irrelevant to questions of gender.
} 
At a declarative level, it is generally agreed that ancient Athenians condemned the rape of Greek women and considered this type of sexual behaviour wrong and unacceptable. For example, in the so-called 'Constitutional debate' of Herodotus' Histories the Persian Otanes argues against the monarchy, by presenting the negative traits of the tyrant; the worst characteristic of the tyrant is the fact that he rapes women (Hdt. 3.80.5). ${ }^{21}$ Moreover, in Euripides' tragedy Ion (line 436-451) the homonymous hero condemns the God Apollo for having raped Creusa.

Despite this, however, there were several cases where Athenians morally justified forms of sexual violence either by exempting them from punishment or by treating them leniently. ${ }^{22}$ Edward Harris argues that Athenians evaluated sexual violence based on the intent of the aggressor and the consequences of the act for the honour of the victim's male relatives. ${ }^{23}$ Legal procedures did not protect a woman's autonomy, but rather men's control over their female relatives; therefore they were punishable by law only when they were understood as acts of hybris against the rape victim's husband, father or other male kin. ${ }^{24}$ Although Harris accepts that the Athenians recognised women's capacity to give or withhold consent, he further claims that this only mattered when they had to distinguish between the different sexual crimes of adultery (moicheia), seduction and rape. ${ }^{25}$

Rosanna Omitowoju does not interpret ancient Greek rape only as bybris, but also focuses on the meaning of violence (bia and its cognates) for the regulation of the crime in the classical Athenian polis. ${ }^{26}$ However, the central point of her study is the insignificance of woman's consent in the provision of legal protection, which explains why other factors, such as the honour of her guardian (kyrios) or the social status and respectability of the victim, made rape prosecutions unlikely in ancient Athens. ${ }^{27}$

These evaluations of evidence stick to the letter of the law and are in accordance with the legal status of women in the Classical Athenian polis. They treat females as simple objects of men's property and their rape as sexual theft or a challenge to a woman's guardian's (kyrios) authority. For example, the abduction of Helen by Paris (according to Herodotus' and Euripides' versions in Histories and The Trojan Women simultaneously) was a wrong committed against her husband Menelaus and not an insult against the person of Helen. ${ }^{28}$ From this perspective, the perpetrator of rape was legally condemned not

\footnotetext{
${ }^{21}$ Although Herodotus was not Athenian, he was Greek and had migrated to Athens, and was familiar with the Athenian tragedy.

22 See Harris 2006, 299.

23 Harris 2006, 314.

24 Harris 2006, 314-315.

${ }^{25}$ Harris 2006, 315 argues that only the woman who allowed herself to be seduced was punished by certain loss of rights but the woman who was raped was not punished.

26 Omitowoju 2002, 51-71.

27 Omitowoju 2002, 8, 116-133.

${ }^{28}$ Harrison 1997, 190.
} 
because he physically violated the autonomy and privacy of the woman, but because by raping her, he usurped the status and the rights of her guardian (kyrios). ${ }^{29}$

Yet, several literary sources add another dimension, suggesting that Athenian women could speak for themselves and could be held accountable for their acts. ${ }^{30}$ In Herodotus' Histories (440 BC), Mycerinus had intercourse with his daughter against her will. When she strangled herself from grief, he buried her in his cow. Then her mother cut off the hands of the servants who had betrayed her daughter to her father, showing the power of women to retaliate in cases of sexual abuse.

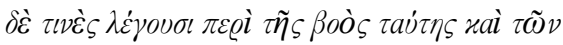

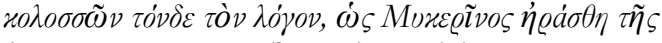

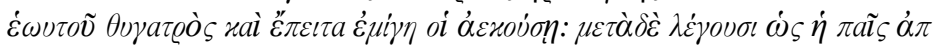

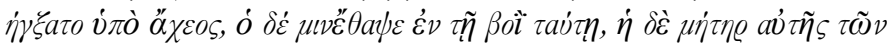

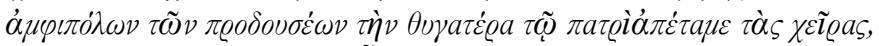

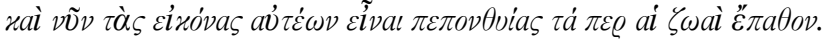

Hdt. (2.131.1-2)

But some tell the following story about the cow and the statues: that Mycerinus conceived a passion for his own daughter and then had intercourse with her against her will; and they say that afterwards the girl strangled herself from grief, and that he buried her in this cow, but that her mother cut off the hands of the attendants who had betrayed the daughter to her father, and that now their statues are in the same condition as the living women were. ${ }^{31}$

Furthermore, in Euripides' The Trojan Women (415 BC), Helen begs for her life claiming that Paris took her by force ... and that he wedded her against her will:

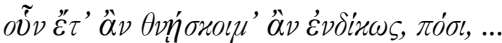

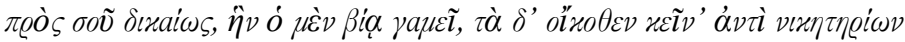

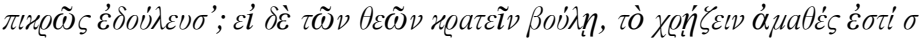
ov $\tau o ́ \delta \varepsilon$.

Eur. The Troyan Women (1. 960-5)

But there was that new husband, Deiphobus, that carried me off by force to be his wife against the will of (Troy). How then, my lord, could I be justly put to death ... by you, with any show of right, seeing that he wedded me against my will, and those my other natural gifts have served a bitter slavery, instead of leading on to triumph? If it is your will indeed to master gods, that very wish displays your folly. ${ }^{32}$

\footnotetext{
${ }^{29}$ Based on the analysis of 1. Harris 2006, 315 who also cites Foxhall 1991, 299 and Porter 1986, 217. 2. Hartmann 2006.

30 Harrison 1997, 191.

31 Translation by A. D. Godley 1920.

32 Translation by E. P. Coleridge 1891.
} 
Yet, Menelaus condemns her for leaving his palace and seeking a stranger's bed willingly and, in this way, he underlies women's capacity to give consent before the sexual encounter and their responsibility for it.

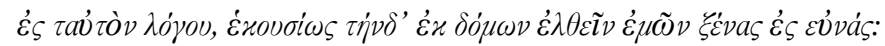

Eur. The Troyan Women (1. 1037-8)

Your thoughts coincide with mine, that she, without constraint, left my palace, and sought a stranger's bed... ${ }^{33}$

It is thus natural to wonder why Greek sources held such a contradictory understanding regarding women and female rape. ${ }^{34} \mathrm{~A}$ possible answer could lie in the complex and fluid nature of social reality. Although the latter is collectively constructed based on the beliefs of the individuals who created it, social reality's guidelines do not completely eliminate individual instincts, motives and reactions, because they interact with biological functions. ${ }^{35}$ In that respect, particularly painful experiences, like sexual mistreatments, could trigger emotions and cause intense reactions that could not be socially constrained. This approach sufficiently explains the idea of Thomas Harrison about a contradictory understanding of women in the Greek social reality based on the necessary coexistence of nature and culture in human societies. ${ }^{36}$

\section{Why rape was really rape}

Edward Harris rightly advises us to approach the Athenians on their own terms. I disagree, however, with his suggestion that we should avoid using the term 'rape'. ${ }^{37}$ A historical analysis of the ancient evidence based on complicated or inaccurate comparable terms will obscure our understanding of the ancient attitudes rather than enhance it. Moreover, a broader application of Edward Harris' argument would render all our modern interpretations overly anachronistic. Since we do not write in ancient Greek, a large number of the English words we use do not include the same connotations as the Greek ones.

When examining ancient sources, the term rape is a comparative unit that helps us to find whether there is any similarity between ancient and modern sexual violence, and of what sort this similarity is. Additionally, the absence of a specific word for rape in the Greek vocabulary does not necessarily imply nonrecognition of the phenomenon on the part of the Athenians. Nancy Rabinowitz, for example, has recently interpreted this absence 'as the ideological effect of the Greek effort to make rape less problematic assimilating it to other concepts. ${ }^{38}$ In this respect, rape qua rape was not unknown, but the concept

\footnotetext{
33 Translation by E. P. Coleridge 1891.

34 Harrison 1997, 191-192 comes up with the idea of two contradictory understandings of women.

35 Pabdug 1999, 19.

36 Harrison 1997, 191-192; Pabdug 1999, 19.

37 Of the same opinion: Harrison 1997, 188; Ogden 1997, 25; Pierce 1997, 163.

38 Rabinowitz 2011, 16.
} 
was adaptable to changing circumstances and could be punished or pardoned whenever the public interest of the Athenian polis demanded it.

The plot of Menander's Samia (around 314 BC) ${ }^{39}$ offers an example of this understanding. The rape of Plangon by the young, rich Athenian citizen Moschion was forgotten when the rapist fulfilled his civic duty, declared his love (the verb $\sigma \tau \dot{\varepsilon} \varrho \gamma \omega$ here denotes the affection that family members feel towards each other) and married the rape victim, thus restoring her citizen status. ${ }^{40}$

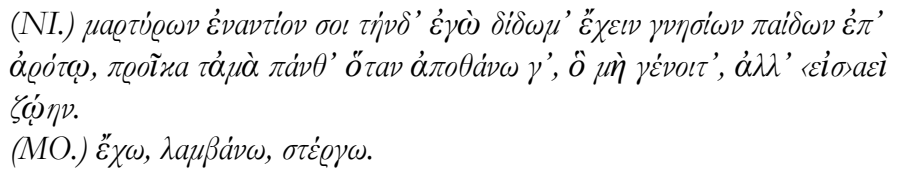

(NI.) Before witnesses I give her to you for the plowing of legitimate children and as dowry all I have, when I die, oh God forbid, but let me live forever.

(MO.) I have her, I get her, I love her. ${ }^{41}$

The observations of Susan Lape that '... the democratic state used marriage as an institution of civic membership and reproduction...' and that 'Menander's plays are about creating the conditions for making legitimate marriages defined by the democratic state ${ }^{, 42}$ provide further support for the argument that rape was decriminalised whenever the public interest of the Athenian polis demanded it. Moschion's belated willingness to follow the Athenian polis' norms, by contributing to the reproduction of legitimate children and the continuation of the Athenian citizenship system, was the outcome that justified the deed. ${ }^{43}$

\section{Rape in Athenian law}

The Athenian legal provisions on rape were not concerned with a woman's sexual exploitation or suffering, but with maintaining male authority and honour. ${ }^{44}$ Legally speaking, rape was a serious crime, but unlike today its wrong was not associated with the harm done to the female victims. Rape was legally condemned because it could cause the dissolution of male estate and could bring into question male responsibility over the oikos 'household'. In this regard, every act of rape launched a double attack on male interests. On the one hand, it offended the male estate, a part of which was the female victim, and on the

\footnotetext{
39 See Arnott 1998, 35-36 for the date of the play.

40 See also Menander in Sommerstein 2014, 35-36 about wiping out the guilt of rape through marriage.

41 Translation by the author.

${ }^{42}$ Lape 2001, 81.

43 Lape 2001, 93; Lape (p. 81) also explains how Pericles' citizen law in 451 BC redefined what the state recognised as a legitimate marriage by requiring that both spouses, man and woman, be Athenian citizens.

44 Lape 2001, 88; Harris 2006, 314-315.
} 
other hand, it theoretically diminished the male status, by challenging the guardian's capacity to control the sexual behaviour of his female household members. ${ }^{45}$ In other words, rape in ancient Athens was a crime committed between men while female bodies were the necessary criminal instruments.

The link of rape's harmfulness solely to the infringement of men's rights was another result of the Athenian ideology that espoused women's ban from the top of the gender hierarchy. The model of gender relations in the oikos worked as a legitimate basis for it. ${ }^{46}$ In the narrow context of this social unit, which was the essential foundation of the polis, a man had the absolute authority over all members of his household, while a woman's role was auxiliary, limited to household management. The subordination of woman to male control was considered a prerequisite for the proper functioning of the oikos and, therefore, all other alternatives of power distribution were deemed socially destructive by popular culture. ${ }^{47} \mathrm{~A}$ typical example of this tendency was the mythical construction of the Amazons, which was intentionally used in Athenian society to reinforce the stereotypical gender roles. ${ }^{48}$ The monumental Amazonomachy on the west metopes of the Parthenon was a popular theme in Greek art with symbolic content relating to female enfranchisement. It served as a warning that women in control could overturn the norms of the civilised male society as well as proof that a society of women without men was doomed to failure. ${ }^{49}$ Even if Adrienne Mayor's research is true and the mythical Amazons were inspired by the real nomad horsewomen of Skythia ${ }^{50}$, Greek inspiration turned reality to a fascinating myth that propagandised male dominance and Greek superiority. ${ }^{51}$

Male control over female sexuality was pivotal for the regulation of reproduction. Sarah Pomeroy writes that 'every generation the members of the oiko $i$ were charged with the perpetuation of the cults of their ancestors as well as the maintenance of the lines of descent. ${ }^{, 52}$ In this framework, maternity was considered a priori a dangerous power, which could be used to overthrow male hierarchy. The submission and loyalty of woman were necessary components for the survival of the individual oikos, in the sense that they prevented the introduction of illegitimate heirs into the man's family and maintained the line of patrilineal descent uninterrupted. Moreover, the same characteristics were essential for the creation and stabilisation of the artificial bond that tied a

\footnotetext{
45 See Harris 2006, 315 cites Foxhall 1991, 299.

${ }^{46}$ MacDowell 1989, 10 writes that the word oikos had a threefold meaning as house, household in the sense of property and family.

47 Wohl 1993, 20.

48 See Lefkowitz 1986, 7, 8, 12; Dowden 1997, 124.

${ }^{49}$ Lefkowitz 1986, 20, 26; Wohl 1993, 35; Blundell 2001, 132.

50 See Mayor 2014, 19.

51 See Lefkowitz 1986, 12; Blundell 1995, 61-62.

52 Pomeroy 1975, 60.
} 
woman to her husband's oikos. ${ }^{53}$ Victoria Wohl associates the control of woman with her quality as an outsider in the oikos, explaining that it was also important for the cohesion of community. ${ }^{54}$ An incomplete transition and assimilation of a woman into her husband's house meant a broken bond not only with the specific oikos, but with the whole community that relied upon the oikoi. ${ }^{55}$ From this point of view, a woman's proper sexual conduct was a basic interest of the oikos and a main concern of the polis. The Athenian community needed women to produce new authentic citizens and was dependent on every oikos providing the appropriate social conditions within which citizens would fulfil their political duties. $^{56}$ For these reasons, Athenian authorities strived to uphold the preservation of the oikos system as the primary source of female restraint and produced legislation that kept men on the top in gender relations.

A woman in Classical Athens had no legal personhood and was constantly under a man's guardianship, usually her father's or her husband's. A natural consequence of this perpetual female dependence on male authority was her inadequate and inefficient legal protection. The inherent sexist logic of the Athenian judicial system deprived woman of any autonomous and direct access to the legal arena. Female legal protection was always subject to the consensus of each guardian (xúoıs) who determined its terms according to his personal interests. ${ }^{57}$ Since only men could appear in courts as litigants, defending only their own rights and interests, it is reasonable to suppose that the feelings or opinions of the affected female victims, even in cases of sexual crimes, were often overlooked.

The decisive importance of other parameters inextricably connected with male interests such as status, honour, respectability, shame and estate integrity, make the private settlement of sexual crimes more likely in the Classical Athenian polis. ${ }^{58}$ Reconciliation and compromise, despite the feelings of the victim, seem more compatible with the spirit of Athenian paternalism toward women as a resolution of the crime of rape. A judicial settlement of a rape charge could have brought about disastrous consequences for a woman's respectability and value, both measured as a loss from her guardian's property. In general, the public and competitive nature of the Athenian courts made them inappropriate places to discuss a woman's life. ${ }^{59}$ From Pericles' funeral speech

\footnotetext{
53 Wohl 1993, 22 notes that a woman's loyalty is necessarily tenuous since she has no basic blood tie to her husband's oikos and her bond is based at best on 'love', at worst on compulsion.

54 Wohl 1993, 20-21.

55 Wohl 1993, 22 refers to Foley 1978, 67 who interpreted control of a woman as the first step in the control of all other non-kin in the oikos structure.

56 Roy 1999, 12.

57 Omitowoju 2002, 122-123.

58 Omitowoju 2002, 122-133; Scafuro 2017, 55-56. Both discuss what it meant for the Athenian women and her guardian not to be able to get married in social and economic terms and argue that cases of rape were probably not litigated but settled by private arbitration.

59 Omitowoju 2002, 131-133.
} 
we assume that the lack of any public discussion around a woman was considered a virtue.

$\mu \varepsilon \delta \varepsilon \tilde{\imath}$ xaì yovaısias $\tau$

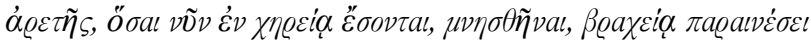

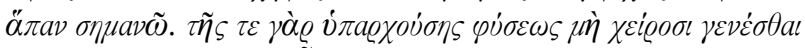

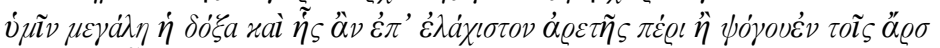

$\varepsilon \sigma \iota x \lambda \dot{\varepsilon} \circ \varsigma \tilde{\eta}$.

Thucydides. 2.45.2, (431 BC)

And since I must say somewhat also of feminine virtue for you that are now widows, I shall express it in this short admonition. It will be much for your honour not to recede from your sex and to give as little occasion of rumour amongst the men, whether of good or evil, as you can..$^{60}$

However, this quiescence also limited any public knowledge about a woman, making her reputation vulnerable to rumour and false accusations ${ }^{61}$ From this perspective, her plaintiff-guardian could never have controlled how the defendant would describe the raped woman's sexual conduct, which could damage her reputation and, in turn, his status more than the rape itself. ${ }^{62}$

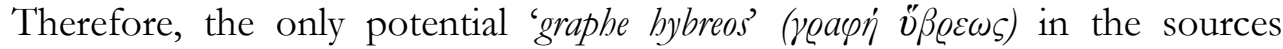
regarding rape, which is described in the oratory of Dinarchus, Against Demosthenes (1.23), around $324 \mathrm{BC}$, did not concern an Athenian citizen woman, but a young musician from Rhodes who was raped during the Eleusinian festival. ${ }^{63}$

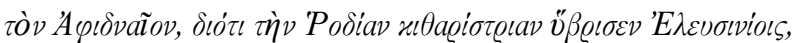

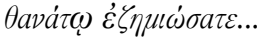

Din. Against Demosthenes, (1.23)

You punished with death Themistius of Aphidnae, because he assaulted the Rhodian lyre-player at the Eleusinian festival...64

Moreover, the concern with a woman's sexual integrity was intense in the Classical Athenian polis specifically regarding her chastity, which was of tremendous importance for her marriage and, consequently, for her reproductive function in the polis. The meaning of chastity, nevertheless, was not identical in all cases. For a young, unwed woman, chastity was equivalent to virginity and determined the size of her dowry. Consequently, rape was a heavy

\footnotetext{
60 Translation by T. Hobbes 1843.

61 Omitowoju 2002, 131.

62 Omitowoju 2002, 131-132.

${ }^{63}$ See Ogden 1997, 30; Cole 1984, 104 and Cohen 1991b, 180 opposed to this.

64 Translation by the author.
} 
burden for her family who then had to pay a much higher dowry. ${ }^{65}$ Yet, for a married woman, chastity meant purity in a more moral sense, which is to say, especially, refraining from extramarital sexual activity. This difference was no doubt due to the fact that a woman could potentially marry a second time, due to the death of her first husband, who was often much older than she, or because of a divorce.

A woman's evaluation according to her chastity denoted her equation with property, both as an independent object, which was to be exchanged for economic or political profit through a marriage arrangement, and as a potential 'transmitter' of property ${ }^{66}$. Her particular quality increased the importance of her sexual activity, in the sense that every instance of female sexual intercourse could potentially fulfil the woman's political duty within the polis, produce legitimate children for the oikoi, ${ }^{67}$ and, simultaneously, transfer her family property to them.

Pericles' citizenship law of $451 \mathrm{BC}$ recognised as legitimate only marriages between two Athenian natives and granted the benefits of citizenship to pure Athenians, namely those whose parents were both Athenians with citizen status. The citizen wife's unique contribution to the continuation of the citizen body made her 'guarantor of male identity, civic status, and citizenship in its entirety'. ${ }^{68}$ Although this fact theoretically upgraded her status and her political function in the society of Classical Athens, it put female sexuality under further pressure. Public concern became greater and this increased vigilance over and supervision of the female body ${ }^{69}$, and may have further reduced women's access to public space. The political significance of female sexuality for the power structure of the Athenian polis left no room for personal sentiments. Legal provisions had no use for the notions of female consent or suffering as distinguishing features of sexual abuse. They needed traditional concepts for the punishment of sexual crimes that would preserve the predetermined gender roles of the oikos.

The interpretation of the law through the lens of this dynamic might explain why the Athenian judicial system provided neither a definition for rape nor a lawsuit specific to it, as it did for other crimes. Suffering and lack of consent are related to the circumstances surrounding the crime and the injuries that rape causes to the victims. In other words, there are potentially important means which, at a first level, help women to speak out, label and describe their experiences and at a second level ensure the appropriate punishment of the perpetrators through the judicial system. In Classical Athens, the patriarchy saw no need for these means. Athenian women were encouraged to remain silent

\footnotetext{
65 See Harris 2006, 315 who cites Porter's observation that: '... in the case of a maiden, rape destroyed her property value on the marriage market, and because defloration polluted, heaped shame on her family' $(1986,217)$.

66 See Pretorius 2017, 58.

67 Pomeroy 1975, 60.

${ }^{68}$ Lape 2001, 98.

69 Lape 2001, 98-99.
} 
about their sexual violation for the benefit of their respectability and, as mentioned above, their guardians would rarely be willing to seek a legal remedy since rape incidents could jeopardise their status, honour and interests. ${ }^{70}$ Moreover, the immaturity of the Athenian judicial system allowed individuals to avoid the specifics of the law and adjust their cases not to punish offences sufficiently but to serve their personal interests. For example, Lysias' argument in his speech 'On the murder of Eratosthenes' (403 BC) that seduction was a more serious crime than rape was written for the defence of Euphiletus, and it might have been based on a series of sophistries that misinterpreted the Athenian law in favour of his client. ${ }^{71}$ From this angle, every incidence of rape was evaluated and punished based on the circumstances, as these were described within the general charges of bia 'violence' or bybris 'injury' that were enacted by male legislators to adequately serve male interests. ${ }^{72}$

In ancient Athens the rape victim's personal sentiments and experiences were legally insignificant, while female consent had quite different consequences in comparison with modern times. Although the Athenians considered a woman capable of giving or withholding consent, and they could distinguish between consensual and non-consensual sexual acts on her behalf, the importance of her consent in establishing sexual crimes was limited by other factors, such as social status and marriage. ${ }^{73}$ In the first place, the right of consent belonged only to free women in Athens. Slaves were at their owner's disposal. According to Xenophon's Oeconomicus (10.12) (c. 400 BC), this special capacity of the free woman had a particular impact on male sexual satisfaction, putting her in a favourable position.

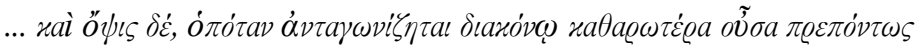

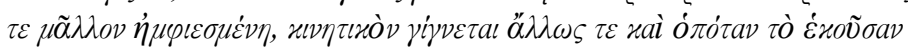

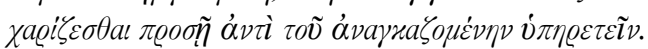

Xen., Oeconomicus (10.12)

As for what my wife looks, when there's a decision to be made between her and the slave girl, then when she is less made up and more tastefully dressed, she becomes an object of desire, and especially because she is granting her favors willingly, whereas the slave has no choice but to yield. ${ }^{74}$

\footnotetext{
70 Omitowoju 2002, 122-133; Scafuro 2017, 55-56.

71 See Harris 1990, 370-377.

${ }^{72}$ For the Greek sanctions against rape see Cole 1984, 99-100; Cohen 1993, 5-16; Ogden 1997, 25-36; Omitowoju 2002, 29-71; Harris 2006, 314-320; Scafuro 2017, 47-50.

${ }^{73}$ Cohen 1993, 6 discusses a spectrum of coercive and non-coercive conduct potentially regulated by law, where violence is at one end of the spectrum, free consent at the other, and a number of gradations of non-consensual and consensual relations lie in between.

74 Translation by E. Harris 2015, 303. However, since the ancient Greek word (ö $\psi \iota \varsigma)$ - opsis means countenance or appearance, I would have preferred to use the word 'how' instead of the word 'what' and the translation would have been: 'As for how my wife looks ...'
} 
However, given the dynamic of gender roles, the question arises whether the consent of a free woman was really important in the sexual relationships within her marriage. The hegemonic role of the master of the house as kyrios, legally fixed and reinforced by the discrepancy in age and education, makes it unlikely that the question of female consent arose in their sexual relations. Therefore, further clarification is useful in understanding the function of female consent. In the Athenian landscape of sexual relations, many forms of coerced sex were normalised and condoned. ${ }^{75}$ Consequently, Athenian men recognised when a free woman did not consent in a sexual encounter with a stranger, rather than acknowledged, in general, that she had a generalised right of consent.

Female consent for sexual activity outside the marriage determined, however, whether a woman could be accused of adultery (poxsia) and be punished for that. Edward Harris underlines that the woman who allowed herself to be seduced was punished by certain loss of rights; no evidence suggests that the victims of sexual violence were subject to similar treatment'. ${ }^{76}$ From this perspective, female consent was not legally insignificant, as it produced important legal consequences for the woman involved both in cases of rape and in cases of adultery (uorxia). ${ }^{77}$ The Athenian law did not make any reference to the raped woman, thus giving the impression that she did not suffer the same fate as the adulterous woman. However, the latter was held personally responsible for her conduct by losing a number of private and public privileges. In this light female consent might have had little to do with the culpability of the male offender, but it determined the female counterpart's culpability. In legal and social terms, a woman in Classical Athens was better off being raped than being adulterous.

Despite the complexity of the problems surrounding a woman's legal protection and the evaluation of her consent, the Classical Athenian polis provided a judicial framework for the conviction of rapists. All cases of rape were actionable under 'the private prosecution of violence', dike biaion - (diren Brai $\omega v)$. Apart from the fact that the designation of rape in ancient Greece linguistically corresponded to 'dike biaion' and the noun bia, violence, a passage from Lysias' speech 'On the murder of Eratosthenes' (Lys. 1.32.1-5) and another one from Plutarch's 'Solon', (23.1) - 75 AD, prove that rape could be charged under this private suit, the so-called dike.

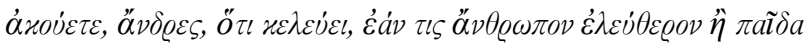

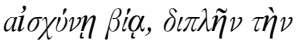

\footnotetext{
75 Cohen 1993, 5-16.

${ }^{76}$ Harris 2006, 315; Carey 1998, 414 also denies that raped women were treated in ancient Athens as women who had been seduced. But Cole 1984, 106-107, Ogden 1997, 30-32, Omitowoju 2002, 130-133 claim the opposite, namely that raped women in Athens were treated in parallel ways to those who had committed adultery.

77 Omitowoju 2002, 230 concludes that consent was not central to the understanding of any Athenian legal term used to designate sexually transgressive activity.
} 


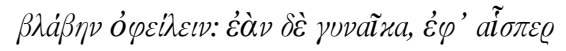

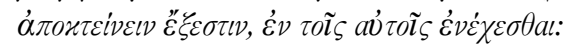

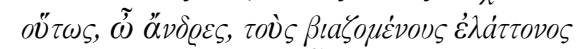

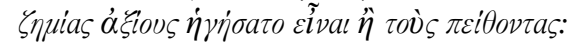

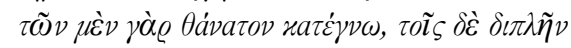

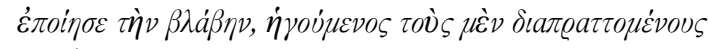

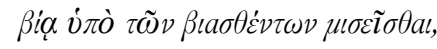

$$
\text { Lys. (1.32.1-5) }
$$

You hear, sirs, how it directs that, if anyone forcibly debauches (shames) a free adult or child, he shall be liable to double damages; while if he so debauches (shames) a woman, in one of the cases where it is permitted to kill him, he is subject to the same rule. Thus, the lawgiver, sirs, considered that those who use force deserve a lesser penalty than those who use persuasion; for the latter he condemned to death, whereas for the former he doubled the damages, ${ }^{78}$

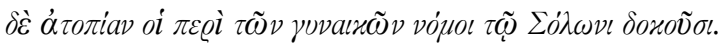

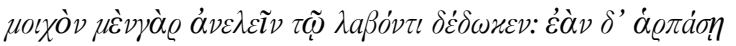

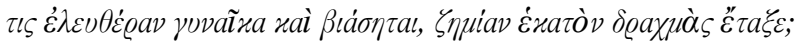

In general, the laws about women enacted by Solon seem very strange. For example, he permitted the captor to kill an adulterer caught in the act: but if a man seized a free woman and raped her, he set a fine of a hundred drachmas for this act... ${ }^{79}$

Hence, whenever the action of dike biaion was brought in the Classical Athenian polis, the prosecutor was the guardian of the female victim and the penalty was a monetary fine paid to him. Moreover, when rape was identified as an act of bybris $^{80}$, namely as a behaviour that was not driven by lust but intended to produce dishonour and shame to others ${ }^{81}$, it gave rise to the public prosecution

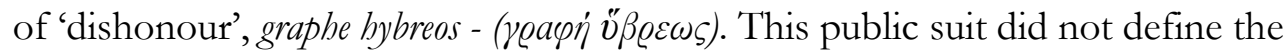
offence, nor did it include a particular penalty. It was a so-called agon timetos $(\tau \imath \mu \eta \dot{\partial} \varsigma \dot{\alpha} \gamma \dot{\omega} \nu)$, thus giving the prosecutor the possibility of suggesting any penalty he wished..$^{82}$ Due to its public nature, this action could be brought by any other citizen of the polis but the guardian of the victim. ${ }^{83}$ The exclusion of the guardian from the procedure attempted to limit the possibility of the

\footnotetext{
78 Translation by W. R. M. Lamb 1930.

79 Translation by the author.

${ }^{80}$ For the definition of the word bybris (dishonour-insult) and its connection with rape: see MacDowell, 1976, 14-31; Fisher 1976, 177-193; Cohen 1991b, 171-188; and

Omitowoju 2002, 29-50.

81 Fisher 1976, 177.

82 See Ogden 1997, 30.

83 See Cole 1984, 99; Ogden 1997, 30, 35.
} 
affected family hushing up the crime. ${ }^{84}$ Despite the scholarly controversy on whether the sources include an actual example of graphe hybreos based on rape, the correlation of the crime with the law of bybris confirms that sexual crimes aroused a great deal of public interest because they could jeopardise the legitimacy of a man's descendants. ${ }^{85}$

Apart from judicial remedies, the Athenian authorities provided the self-help of the Draconian law for justifiable homicide. This law is best described by Demosthenes in his speech, Against Aristocrates (23.53) (middle of the fourth century BC), and only implicitly refers to the crime of rape. According to its content:

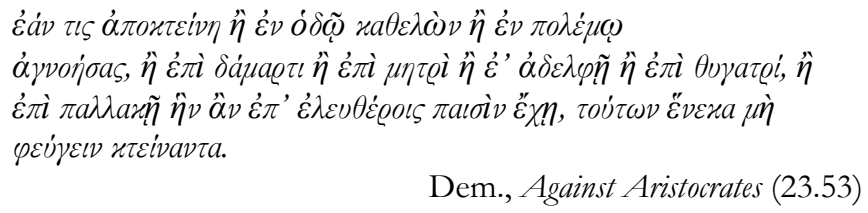

If a man kills another unintentionally in an athletic contest, or overcoming him in a fight on the highway, or unwittingly in battle, or in intercourse with his wife, or mother, or sister, or daughter, or concubine kept for procreation of legitimate children, he shall not go into exile as a manslayer on that account. ${ }^{86}$

The guardian's right to kill the rapist on the spot if he caught him epi, translated as 'on the top of, 'with/at', or just 'over', a woman under his protection without being exiled or punished is of great sociological importance. It shows that the Athenian polis accepted death as a fair punishment for the rape of women. Yet, this is the only legal provision that directly refers to the female rape victims, who, otherwise, were invisible in the eyes of the Athenian law. Perhaps the reference to women in this particular provision was connected to its purpose and specified its range and scope. The right to kill was fair revenge provided by the law to the man who had his property violated. The women referred to in the provision were the only parts of the property for which the right was granted.

\section{Rape in literature}

The legislation on sexual assault ensured the socio-cultural norms of sexuality that the Athenian system required. Yet, literature discusses the sexual violation of women in different terms, revealing that actual social practices could diverge significantly from the official legal framework, and take into account the victims' feelings. The most outstanding example of this divergence was the literary

\footnotetext{
${ }^{84}$ See Ogden 1997, 36 and Cohen 1991a, 129-130 for examples where the husband, despite the rape, might have wished to live with his wife. However, Omitowoju 2002, 4950 includes the guardian as a potential prosecutor of this process.

85 Ogden 1997, 35; Lape 2001, 81-99.

86 Translation by A. T. Murray 1939.
} 
narrative of Creusa's rape in Euripides' Ion. In this tragedy, Euripides describes the painful experience of rape from a woman's perspective. The way he unfolds the plot of his tragedy and constructs the character of Creusa indicates his acknowledgement that the impact of rape went far beyond any physical injuries and caused deep psychological trauma to the woman involved, leaving her shattered and scared. The particular emphasis on Creusa's emotional situation, which is divided into different stages, indicates that Euripides was aware of how a female victim would have bodily and socially responded to the trauma of rape.

First, the linguistic formulation in the prologue explicitly dissolves any suspicion about the nature of Apollo's union with the heroine Creusa in contrast to Mary Lefkowitz's claims that this union was not forced.

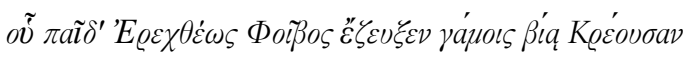

Eur. Ion (10-11)

Phoibos forcefully yoked in marriage the child of Erechtheus,

Creusa $^{87}$

The use of the word bia ( $\beta$ ra) 'violence or force' demonstrates the involuntary nature of their encounter and, simultaneously, confirms that Creusa was the forced participant of it. ${ }^{88}$

In line 288 of the text, Creusa makes her first reluctant reference to the incident of rape when she tells Ion that she hates the place dear to the god Apollo, because 'she was involved in a shame in the cave'. ${ }^{89}$ Later, in line 336 she shows a willingness to confide her story but due to her shame, a common symptom of rape, she hesitates to open up: 'so hear the story - but we are ashamed ${ }^{90}$ ( $\mu \tilde{v} \theta 0 v .-\dot{\alpha} \lambda \lambda^{\prime}$ ai $\left.\delta o \dot{u} \mu \varepsilon \theta a\right){ }^{91}$ In lines 859-869, Euripides depicts his heroine emotionally collapsing on the grounds of her prolonged feelings of shame and guilt.

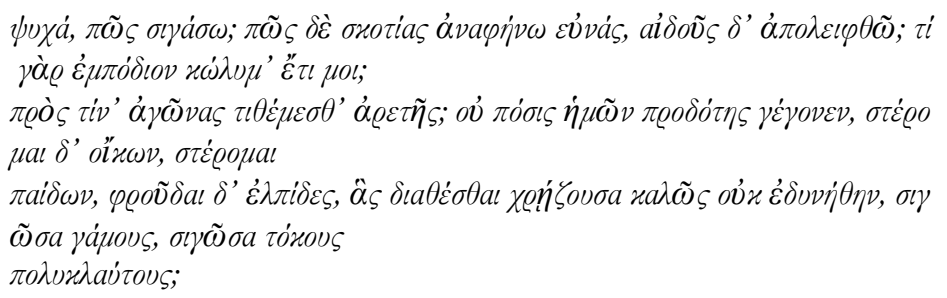

O my soul, how shall I be silent? But how shall I reveal the hidden bed, and depart from shame? What hindrance is still in my way?

\footnotetext{
${ }^{87}$ Translation by the author.

${ }^{88}$ Of the same opinion are: Scafuro 1990, 140; Harris 2006, 320-321.

89 Translation by the author.

${ }^{90}$ Translation by the author.

${ }^{91}$ See Scafuro 1990, 136-159 for the shame-directed discourse of Creusa's sexual violation by Apollo.
} 
Against whom am I set in a contest of virtue? Is not my husband my betrayer, and I am deprived of a house, deprived of children; the hopes are gone which I wished to arrange well but could not, when I was silent on this union, silent on the lamented birth. ${ }^{92}$

The traumatic experience of rape itself as well as its aftermath caused Creusa's total resignation and gradually led to her disclosure of what happened to her. Adele Scafuro detects a social nuance in Creusa's removal of shame, stressing that, 'only when she thinks she has lost everything - home, husband, the hope of future children and of discovering her lost one, does Creusa remove the veil of shame to speak of the god's rape'. ${ }^{93}$ However, it is also important to notice that Euripides seems to understand the nature of shame as a psychological reaction to sexual abuse. From this point of view, Creusa proceeded with a voluntary disclosure in a state of emotional shut-down caused by the ongoing shame and pain described in lines 874-880:

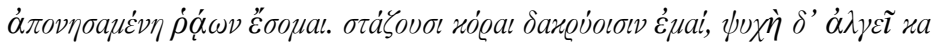

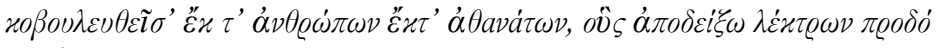

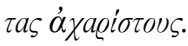

Eur. Ion (874-880)

I will no longer conceal this bed, so that I may cast off this load from my breast and be at ease. Tears fall from my eyes, my soul is in pain, victim of plots by men, by gods, whom I will show to be ungrateful betrayers of the beds they forced. ${ }^{94}$

As a result of a painful internal process, Creusa confesses her tragic experience in the lines 800-906:

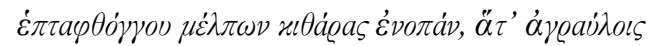

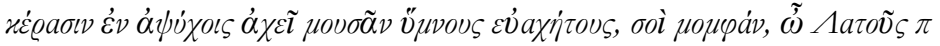

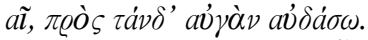

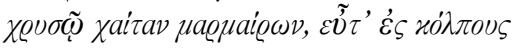

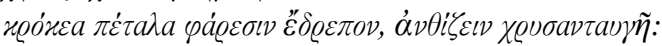

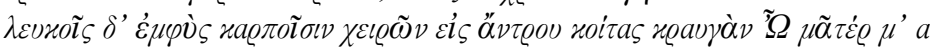

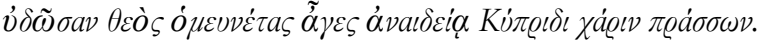

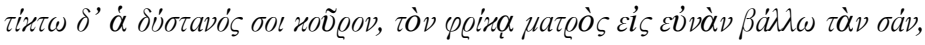

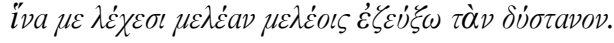

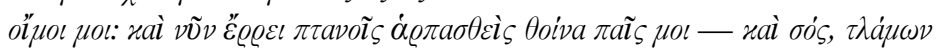

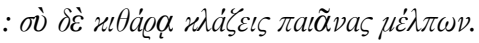

Eur. Ion (881-906)

O you, who cause a voice to sing from your seven-stringed lyre, a voice that lets lovely-sounding hymns peal forth in the rustic lifeless horn, son of Leto, I will blame you before this light. You came to me, your hair glittering with gold, when I was plucking into the folds of

\footnotetext{
92 Translation by R. Potter 1938.

${ }^{93}$ Scafuro 1990, 144.

94 Translated by R. Potter 1938.
} 


\begin{abstract}
my robe yellow flowers to bloom with golden light; grasping my white hand in yours, you led me to the bed in the cave, hearing me call on my mother, god and consort, shamelessly paying homage to Aphrodite. I, the unhappy one, bore you a son, whom in fear of my mother I placed in that bed of yours, where you joined with me, the miserable, the unfortunate one, in unhappy union. Alas! and now my son and yours, oh cruel one, is gone, torn apart, a feast for birds; but you are singing to the lyre, chanting hymns. ${ }^{95}$
\end{abstract}

And finally, Creusa asserts that she was sexually assaulted by the god in lines 939-941:

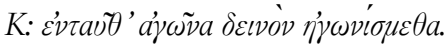

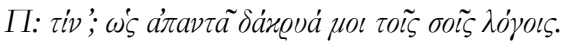

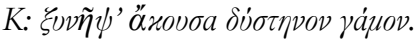
C: There I fought a terrible contest.
T: Which contest? How my tears meet your words.
C: Against my will, I joined in an unhappy union with Phoebus. ${ }^{96}$

Euripides portrays how an Athenian woman might have felt during her rape and pays attention to give a sincere depiction of her dramatic experience. Elements of this monologue seem relevant even today. The most indicative is Creusa's cry

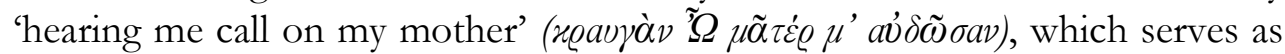
indisputable proof of Apollo's coercive act. ${ }^{97}$ The gloomy atmosphere of her description based on the adjectives 'the unhappy, the miserable' dustanos

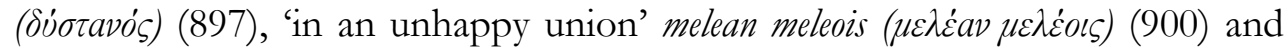

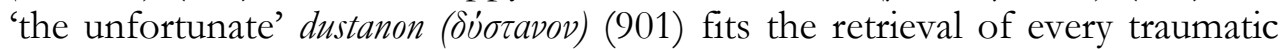
memory. Creusa's overwhelming anger and diffused distress are typical reactions to forcible intercourse. ${ }^{98}$ Finally, the emotionally charged expression

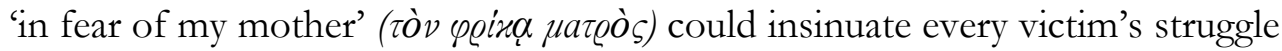
with the social stigma attached to rape. Scafuro was the first to uncover the novelty of Euripides' public accounts of the sexual abuse of women, which recognised their trauma on a personal level. ${ }^{99}$ Corina Martha Brunini-Cronin recently went a step further noticing that Euripides presents the disposition of the sexual aggressor and his treatment of the victim afterwards (if positive) as important not only for his eventual legal treatment but also for the victim's recovery. ${ }^{100}$

Nevertheless, the analysis of Creusa's rape through the lens of rape culture lends a fresh perspective to Euripides' articulation. It gives insight into

\footnotetext{
95 Translated by R. Potter 1938.

96 Translated by the author.

${ }^{97}$ See Scafuro 1990, 157.

98 Omitowoju 2002, 186 for the comparison between the description of rape in Ion and

Epitrepontes.

${ }^{99}$ Scafuro 1990, 150.

100 Brunini-Cronin 2016, 71.
} 
the clash between the human experience of rape and the Athenian polis' attitude toward it and divulges the antithesis between the human condition during and after rape and the official agenda of the Athenian community for gendered socialisation. It also discloses that Euripides' literary contrivances, such as the lyrical depiction of the experience that blurs the boundaries of rape with these of consensual intercourse or the happy ending of the play in which the survivor appears 'vindicated' despite the rapist god's restoration, operated as other 'rape myths' which subjected the Athenian audience to an indirect indoctrination tacitly implanting attitudes recommended by the Athenian polis.

The parallels between Euripides' contrivances and attitudes of rape culture, in the sense that they both aim to confuse sex with violence, treat the rapist leniently, and minimise the seriousness of sexual violence, can be enlightening to us by disclosing the distorting power of cultural practices when the latter are being exploited by systemic patriarchies. As, for example, Euripides' poetry communicates the Athenian conception of rape as a fight to read consent and desire into all other responses of the raped victims, so, too, do contemporary means, inculcating us with prejudicial beliefs about sexual assaults that are far from the truth. The tremendous impact of perpetually institutionalised misogyny is obvious even among remarkable modern critics such as Mary Lefkowitz or Anne Pippin Burnett, who interpret Apollo's and Creusa's encounters as seduction solely based on the extent of the victim's resistance. ${ }^{101}$

The second Athenian literary articulation of a woman's rape experience occurred in Aeschylus' tragedy Agamemnon. The heroine Cassandra disclosed her rape by Apollo before predicting Agamemnon's murder and her own death in a brief and puzzling way in lines 1202-1212.

\begin{tabular}{|c|c|}
\hline Ka: $\mu a ́ v \tau \iota \varsigma ~ \mu ’$ $\dot{c}^{\prime} \varepsilon \varepsilon$. & Xo: $\mu \tilde{\omega} v$ xaì $\theta \varepsilon o ́ \varsigma ~ \pi \varepsilon \varrho ~ i \mu \dot{\varepsilon} \varrho \omega ~ \pi \varepsilon \pi \lambda \eta \gamma \mu \dot{\varepsilon} v o \varsigma ;$ \\
\hline 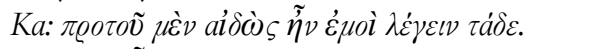 & Xo: $\dot{\alpha} \beta \varrho u ́ v \varepsilon \tau a \iota ~ \gamma \grave{\alpha} \varrho \pi \tilde{\alpha} \varsigma \tau \iota \varsigma \varepsilon \tilde{v} \pi \varrho a ́ \sigma \sigma \omega \nu$ \\
\hline 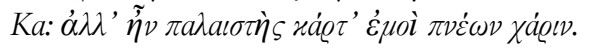 & 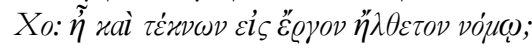 \\
\hline 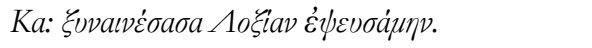 & 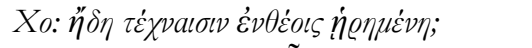 \\
\hline 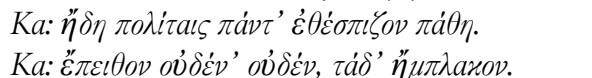 & Xo: $\pi \tilde{\omega} \varsigma \delta \tilde{\eta} \tau^{\prime} \not ̈ \nu a \tau o \varsigma \tilde{\eta} \sigma \theta a \Lambda \circ \xi i o v$ \\
\hline
\end{tabular}

Aesch. Ag. (1202-1212)

Ca: The seer Apollo appointed me to this office. Ch: Can it be that he, a god, was smitten with desire?

\footnotetext{
101 Lefkowitz 1993, 27-29 writes that Creusa did not give her consent at first, though it is also true that she does not try to escape. The reason for her sorrow is not her intercourse with the God, but that he abandoned her and her son, while Burnett 1967, 91 explains that Creusa's allegation of rape is false, connecting it to her status which requires her to be reluctant. And she continues by claiming that when her reluctance is established, Creusa has no complaint to make about her seduction; her charge is not one of rape but of desertion and lack of support.
} 


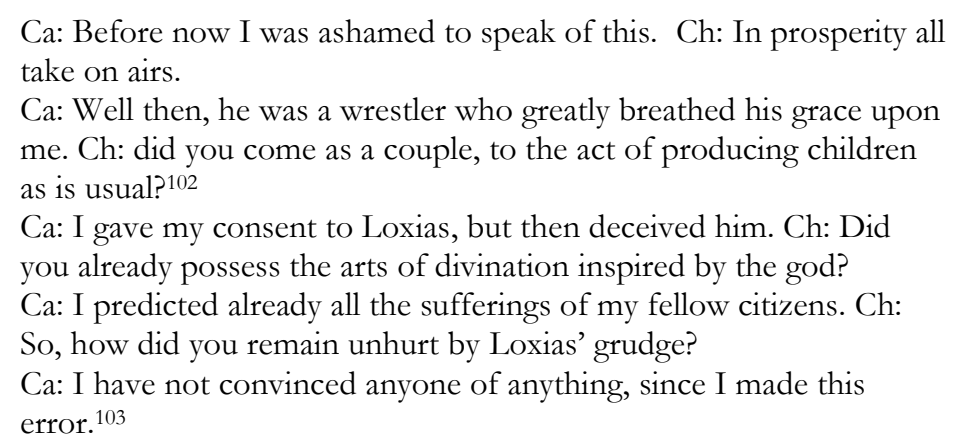

Aeschylus and Euripides have a lot in common in their portrayals of the traumatic experience of rape. In Cassandra's confession 'before now I was

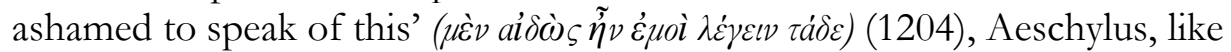
Euripides, exposes the persistent shame and guilt that a survivor of a sexual assault feels. ${ }^{104}$ Respectively, he illustrates Cassandra's sexual violation as a physical contest, 'Well then, he was a wrestler who mightily breathed his grace

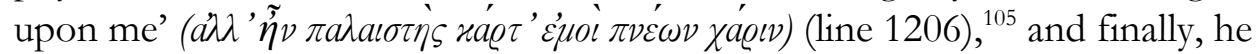
narrates the incident of rape following a foggy and obscure pattern. Cassandra's words 'who greatly breathed his grace upon me' ( $\chi$ á $\iota v)$, and her avoidance of an answer to the chorus's specific question in line 1207, 'did you come as a couple, to the act of producing children as is usual?

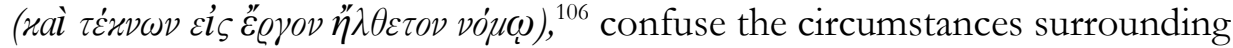
the act, spreading doubt about the type of encounter and disbelief about Cassandra's credibility. Nevertheless, Aeschylus adds in Cassandra's storytelling a clear sense of self-blame that Euripides omits in the case of Creusa. Aeschylus holds Cassandra responsible for the harm that befell her in line 1208, 'I gave my consent to the God, but then deceived him'

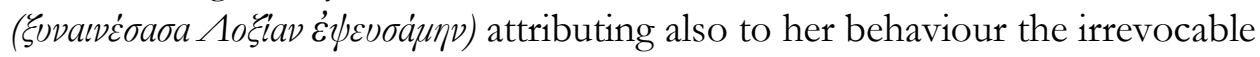
lack of her credibility in lines 1211-1212 'Chorus: So, how did you remain unhurt by Loxias' grudge? Cassandra: I have not convinced anyone of

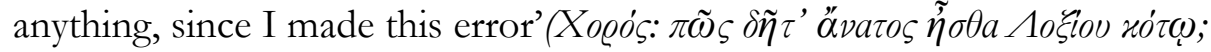

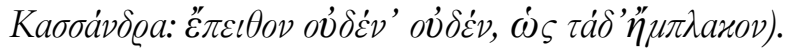

\footnotetext{
102 Translation by P. Debnar 2008.

103 Translation by the author (lines 1208-1212).

104 See Scafuro 1990, 144-145 for the comparison between Creusa's and Cassandra's disclosure on the state of despair and the social nature of shame.

105 Both Scafuro 1990, 156 and Debnar 2010, 132 refer to Fraenkel regarding line 1206, who thinks that the metaphor is literal, and that the god sets himself to overpower the maiden, although he believes 'it is not merely brute force which is here at work'; BruniniCronin 2016, 56 mentions also the similarity in the description of sexual attack between the two plays.

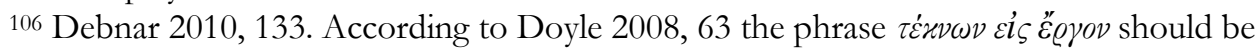

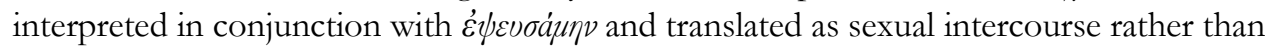
child-bearing itself.
} 
Within this framework, Cassandra's rape narrative is even more indicative of behaviours that represent the 'rape culture'-model. On the one side, Cassandra personifies every female victim who feels responsible for her rape and covers her shameful experience to avoid the blame. On the other side, her punishment embodies the usual suspicion with which society treats all sorts of sexual accusations, reinforcing victim-blaming. ${ }^{107}$ The diffused doubt of her speech reminds us of the present-day rape stories which are reported to the police or told in court, without being believed. Cassandra's particular social exclusion equates with the peculiar marginalisation that modern rape victims go through, something which severely endangers their physical and social security. As Cassandra lost her believability after her deception, modern victims also bear a social stigma allowing the other members of society to trample over their dignity, integrity and self-worth.

In addition, given the Athenians' outright misogyny, the mystical and fuzzy narrative of Cassandra can operate as another example of the eternal view of female nature as sly and deceitful. Similar assumptions are common even today shifting the blame onto the raped women for making themselves vulnerable to rape due to their 'inappropriate choices'.

Other evidence that Athenian men were aware that the rape of a woman was a shocking human experience is found in Menander's comedy Epitrepontes. Early in the play, the hetaira Habrotonon, while talking with the slave Onesimos, describes the reaction of the Athenian citizen woman, Pamphile, after her rape during the Tauropolia night-festival.

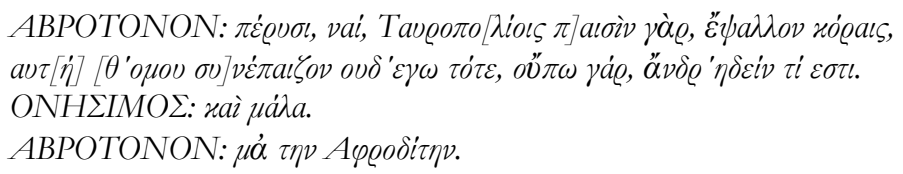

HABROTONON: Yes, the Tauropolia, last year. I played for some young girls and [shared] their games myself. Nor did I then ... what men are like.

ONESIMOS: Yeah, right.

HABROTONON: By Aphrodite, I didn't!108

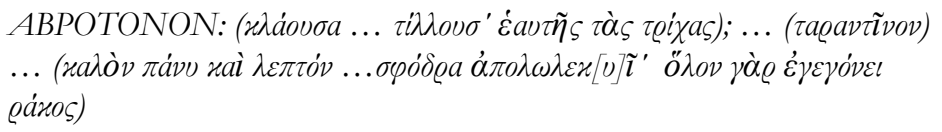

Men. Epit., (487-490)

HABROTONON: She was there with us and wandered off. Then all at once she ran up by herself, sobbing and tearing her hair. Gods! Her cloak, so filmy and lovely, was quite ruined, all torn to rags. ${ }^{109}$

107 Heller 2018.

108 Translated by W. G. Arnott 1979.

109 Translated by W. G. Arnott 1979. 
According to Habrotonon, Pamphile's condition after her rape resembles the condition of any modern rape victim. The description of her reaction, though exclusively relying on the use of symbols, recalls every victim's suffering. Pamphile's hysterical depiction 'sobbing and tearing her hair' (xגáovoa ... $\left.\tau i \lambda \lambda o v \sigma^{\prime} \dot{\varepsilon} a v \tau \tilde{\eta} \varsigma \tau \grave{\alpha} \varsigma \tau \varrho i x a \varsigma\right)$, reminiscent of funeral behaviour, vividly expresses the raped woman's sorrow and distress (487). ${ }^{110}$ The visual symbol of her 'cloak'

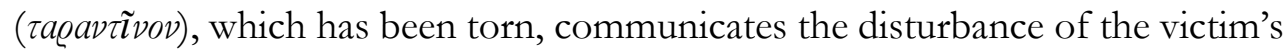
emotional situation and stresses the antithesis between its previous and present condition. Before the tragic incident it was 'so filmy and lovely', (a sentence which stimulates the sense of touch), but after the traumatic experience of rape

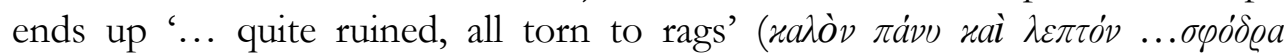

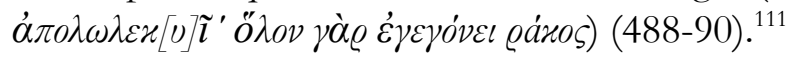

Moreover, Karen Pierce claims that the same symbol can figuratively denote female attractiveness, and it is intentionally used by the poet to sexually excite the audience. ${ }^{112}$ Another interesting interpretation is that of Alice Glazebrook, which connects the cloak both with Pamphile's higher social status and with her low personal value after the rape. ${ }^{113}$ According to Alice Glazebrook, the text emphasises the quality of the garment to point out Pamphile's social position in the Athenian polis, while the torn garment refers to her torn hymen implying her loss of respectability. ${ }^{114}$ Within this framework, the ruins of her clothes illustrate, by extension, Pamphile's body insinuating her responsibility for the violence committed against her. ${ }^{115}$

In addition to this, the dialogue of Habrotonon and Onesimos includes signals suitable for decoding the appropriate Athenian attitudes concerning each gender's sexual behaviour. Firstly, the empathy of Habrotonon toward the woman victim is strongly opposed to Onesimos' impassiveness. The sharp antithesis between the two characters might reflect Menander's intention to underscore general gender differences, alluding to the fact that a person of the same gender has a better understanding of the issues related to his/her sex. For example, Habrotonon as a woman could comprehend the trauma of Pamphile better than Onesimos, a man. ${ }^{116}$

Secondly, Onesimos' sarcastic answer, 'Yeah, right' (xaì pá̀a) to Habrotonon's previous comment regarding her sexual inexperience evinces the Athenian stereotype that women had a seductive and insatiable sexual nature.

\footnotetext{
110 Pierce 1997, 164; Gardner 2013, 128; Glazebrook 2015, 82.

111 Pierce 1997, 164; Gardner 2013, 128.

112 Pierce 1997, 179 explains how the torn silken cloak can work as a sign of a respectable woman who previously was pure and virginal or as an indication of sexual attractiveness and excitement.

113 Glazebrook 2015, 87.

114 Glazebrook 2015, 87.

115 Glazebrook 2015, 95.

116 Pierce 1997, 165.
} 
Between the lines of their dialogue, we can read attitudes similar to our familiar victim-blaming or shaming comments that surround discussions of rape cases. In particular, Alice Glazebrook's theoretical construction of a hierarchy of violence that highlighted the distinctions in attitude toward sexual violence dependent on the status of the victim ${ }^{117}$ reminds us of a pervasive present assumption that promiscuous women, or women who belong to socially marginal groups, are more prone to rape, maintaining a sense of false social security.

The last passage which can prove that Athenian men understood the evil nature of rape and its destructive consequences for women on a personal level is drawn from the fragmentary tragedy of Euripides' Auge. Although there is much scholarly controversy regarding this play, since Euripides' initial story was lost and it was later restored based on the versions of Moses of Chorene and Strabo, both Moses and Strabo agree that Auge was raped by Hercules and bore a son, Telephus. ${ }^{118}$ After her rape, she experienced a series of crises defending herself alone either to her father, Aleus, or the goddess Athena. ${ }^{119}$ No matter what version of the myth we choose to follow in line 265, Hercules is depicted as apologising to Auge by expressing his remorse and blaming the wine for his misdeed:

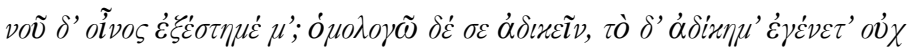

$$
\begin{aligned}
& \text { Éxoúoıov. } \\
& \text { Eur., Auge, } 265
\end{aligned}
$$

'My mind was confused by the wine; and I admit that I wronged you, but the misdeed was done involuntarily. ${ }^{\prime 20}$

The portrayal of Hercules' apology to Auge confirms that the poet was able to conceptualise the rape of women not only as a wrongful act that damaged male property rights, but also as an independent injury of said women. Therefore, he has Hercules excuse himself to Auge and not her father, Aleus. Furthermore, the fact that this act-play was presented to the Athenian public proves that the practice was not just wishful thinking on the part of the poet or a product of his broader education in comparison to that of his audience, but that the Athenians were actually familiar with it since they were willing to see it staged. Another interesting point is that as soon as he states a caring practice for the female victim of rape, Euripides emphasises the callous Athenian attitude using the 'wine' as a mitigating factor for ensuring impunity for the perpetrator.

Also, even though official policies today are dedicated to stopping rape and punishing the offenders, similar excuses such as the previous use of

\footnotetext{
117 Glazebrook 2015, 90.

118 See Anderson 1982, 165-171 for the description of the two versions and their differences.

119 At this point I adopt what Anderson 1982, 170-171 suggested, namely that Auge recalls what Hercules said to her and that he did not come back to rescue her himself.

120 Translation by the author.
} 
alcohol or other substances often create attitudinal obstacles to effective prosecution and punishment of sex offenders. The claim of alcoholic intoxication especially is a frequent defence strategy for the attackers, either by blaming alcohol for the impaired functioning of their cognitive capacity and their sexual aggression or by claiming that the victim consented because of her inability to effectively resist the attack. Hence, even today, the same excuse assists sex offenders to exploit legal intricacies and judicial gaps to escape punishment.

What really differentiates this ancient society from modern Western ones is related to its divergent thinking about male rape. The ancient Athenians recognised the rape of males to a much greater extent than we do. Several Greek myths that involved abductions and sexual abuses of males by other males or gods were invented to justify different theoretical approaches; e.g. the legends of Ganymedes and Chrysippus, who were respectively abducted and raped by the king of the gods, Zeus, and the heir of the throne of Thebes, Laius. ${ }^{121}$ Furthermore, the Athenian oratory and comedy also dealt with same-gender relations and homosexual inclinations transmitting a contradictory moral judgement on the subject; e.g. Aeschines' speech against Timarchus who charged him with prostitution and Aristophanes in Thesmophoriazusae lines 35-276 or Ecclesiarusae lines 103-104. ${ }^{122}$

So even though it is obvious that the rape of males is a topic more correlated with the role of homosexuality and pederasty in ancient Greek culture and, as such, is irrelevant to the scope of this article, I will remark that Athenians believed that male rape induced the lack of masculinity depriving men of their normative role as warriors and city rulers. ${ }^{123}$ This equation of rape with feminisation reminds one somehow of the modern fear of many rape victims, who avoid admitting and reporting the crime so that they will not be characterised as homosexual.

\section{Conclusion}

Looking at the extant evidence through the eyes of the modern concept of rape culture we can comprehend how the Athenian attitudes toward sexual violence underpinned gender inequality and ensured male supremacy. This direct comparison of rape myths between Classical Athens and contemporary society offers a broader perspective on gender issues that we cannot achieve through the narrow lens of relativism. It can unveil a similar systematic exploitation of cultural mechanisms for the survival of patriarchal power structures and can pinpoint perpetual socio-cultural elements that benefit men by imposing sex stereotypes and by desensitising societies to interpersonal and sexual violence. It can provide a broader understanding of the incessant existence of sexual

121 Symonds 2010, 20-21.

122 Hubbard 2012, 86-162.

123 Hubbard 2012, 8. 
violence against women in all human societies and it can delimit the role of culture in the phenomenon of rape.

In addition to this, by taking into consideration the evidence in this article, we find that different cultural environments influence the notion of harm from sexual assault, in the sense that they determine whether the womensurvivor will share the results of their sexual abuse with others, but they do not alter the trauma in the victims as the latter affects the core of human nature transcending historical and cultural contexts. This knowledge is precious for enhancing women's and men's well-being in the modern world, as it paves the way for a cross-cultural investigation of sexual violence.

Sotiria Rita Koutsopetrou-Møller

divesuif@hotmail.com

University of Bergen 


\section{References}

Anderson, S. W. 1982: 'Euripides' Auge and Menander's Epitrepontes', GRBS 23(2): 165-177.

Arnott, W. G. 1979: Menander: Aspis to Epitrepontes, vol. I. Cambridge: Harvard University Press.

Arnott, W. 1998: 'First Notes on Menander's Samia', ZPE 12: 35-55.

Bal, M. 1994: 'Scared to Death', in M. Bal \& I. E. Boer (eds), The Point of Theory: Practices of Cultural Analysis, 33-47. New York: Continuum.

Balot, R. K. (ed.) 2009: A Companion to Greek and Roman Political Thought, 3-19. Oxford: Wiley-Blackwell.

Blundell, S. 1995: Women in Ancient Greece. London: British Museum Press.

Blundell, S. 2001: Women in Classical Athens. London: Bristol Classical Press.

Brown, P. G. McC. 1993: 'Love and Marriage in Greek New Comedy', CQ 43(1): 189-205.

Brownmiller, S. 1975: Against Our Will: Men, Women and Rape. New York: Simon $\&$ Schuster.

Brunini-Cronin, C. M. 2016: 'Victims or Objects? The Representation of Sexual Violence in Greek Tragedy', PhD diss. Durham theses: Durham University. Available at: http://etheses.dur.ac.uk/11378/

Burnett, A. 2016: 'Rape Culture', in N. A Naples (ed.), The Wiley Blackewell Encyclopedia of Gender and Sexuality Studies, 1-5. DOI: 10.1002/9781118663219.wbegss541. Malden: John Wiley \& Sons.

Burnett, A. P. 1962: 'Human Resistance and Divine Persuasion in Euripides, “Ion”, CPh 57(2): 89-103.

Burnett, A. P. 1971: Catastrophe Survived: Euripides Plays of Mixed Reversal. Oxford: Clarendon Press.

Burt, M. R. 1980: 'Cultural Myths and Supports for Rape', J Pers Soc Psychol. 38(2): 217-230.

Carey, C. 1995: 'Rape and Adultery in Athenian Law', CQ 45(2): 407-417. 
Cohen, D. 1991a: Law Sexuality and Society: The Enforcement of Morals in Classical Athens. Cambridge: Cambridge University Press.

Cohen, D. 1991b: 'Sexuality, Violence, and the Athenian Law of bubris', G\&R 38(2): 171-188.

Cohen, D. 1993: 'Consent and Sexual Relations in Classical Athens', in Laiou (ed.), 5-16.

Cole, S. G. 1984: 'Greek Sanctions against Sexual Assault', CP 79(2): 97-113.

Coleridge, E. P. 1891: The Plays of Euripides, vol. I. London: George Bell \& Sons.

Deacy, S. \& Pierce, K. F. (eds) 1997: Rape in Antiquity. London: The Classical Press of Wales.

Debnar, P. 2010: 'The Sexual Status of Aeschylus' Cassandra', CP 105(2): 129145. (Aeschylus' Agamemnon, lines 1202-1207, 1209-1211).

DioGuardi, S., Wellman, A. \& Reddington, F. P. 2019: 'Blaming Beauty for the Beast: A Jungian Explanation for the Persistence of Patriarchal Patterns', Journal of Cultural Analysis and Social Change 4(1): 1-12.

Dover, K. J. 1974: Greek Popular Morality. Oxford: Basil Blackwell.

Doyle, A. 2008: 'Cassandra - Feminine Corrective in Aeschylus's Agamemnon', ACL 51(1): 57-75.

Fisher, N. R. E. 1976: 'Hybris and Dishonour I', G\&R 23(2): 177-193.

Foley, H. P. 1978: “Reverse Similes" and Sex Roles in the Odyssey', Arethusa 11(1-2): 7-26.

Foxhall, L. 1991: 'Response to Eva Cantarella', in M. Gagarin (ed.), Symposion 1990: Vorträge zur Griechischen und Hellenistischen Rechtsgeschicbte, 297-304. Köln: Bohlau.

Fraenkel, E. (ed.) 1950: Aeschylus Agamemnon 1. Oxford: Clarendon Press.

Gardner, H. H. 2013: 'Ventriloquizing Rape in Menander's Epitrepontes', Helios 39(2): 121-143.

Glazebrook, A. 2015: 'A Hierarchy of Violence? Sex Slaves, Parthenoi, and Rape in Menander's Epitrepontes', Helios 42(1): 81-101. 
Godley, A. D. 1920: Herodotus. Cambridge: Harvard University Press.

Harris, E. M. 1990: 'Did the Athenians Regard Seduction as a Worse Crime than Rape?', CQ 40(2): 370-377.

Harris, E. M. 1997: 'Review Article Susan Deacy and Karen Pierce (eds), Rape in Antiquity: Sexual Violence in the Greek and Roman Worlds', Classical Views 40(16): 483-496.

Harris, E. M. 2006: 'Did Rape exist in Classical Athens? Further Reflections on the Laws about Sexual Violence', in E. M. Harris (ed.), Democracy and the Rule of Law in Classical Athens: Essays on Law, Society, and Politics, 297-332. Cambridge: Cambridge University Press.

Harris, E. M. 2015: “Yes” and "No" in Women's Desire', in Masterson, Rabinowitz \& Robson (eds), 298-314.

Harrison, A. R. W. 1968: The Law of Athens: The Family and Property, vol. 1. Oxford: Oxford University Press.

Harrison, T. 1997: 'Herodotus and the Ancient Greek Idea of Rape', in Deacy \& Pierce (eds), 185-205.

Hartmann, E. 2006: 'Rape', in H. Cancik \& H. Schneider (eds), Brill's New Pauly. Brill's New Pauly, Antiquity Volumes [Online]. Available at: https://referenceworks-brillonline-com.pva.uib.no/entries/brill-snewpauly $/$ rape-e12200890?s.num $=27 \&$ s.start $=20$

Heller, S. 2018: 'Hard to Believe: Conditions that discredit Victims of Sexual Assault and Sanction Esteemed Offenders'. The Humanist.com [Online]. Available at:

https://thehumanist.com/magazine/may-june-2018/features/hard-to-believe

Hobbes, T. 1843: The English Works of Thomas Hobbes of Malmesbury - Thucydides. London: Bohn.

Hubbard, T. K. (ed.) 2003: Homosexuality in Greece and Rome: A Sourcebook of Basic Documents. Berkeley: University of California Press.

Karakantza E. D. 2004: 'Literary Rapes revisited. A Study in Literary Conventions and Political Ideology', Mètis. Revue d'anthropologie du Monde Grec Ancien: Philologie, Histoire, Archéologie 22: 29-45. 
Kalra G. \& Bhugra, D. 2013: 'Sexual Violence against Women: Understanding Cross-cultural Intersections', Indian J Psychiatry. 55(3): 244-249.

Kocka, J. 2003: 'Comparison and Beyond', History and Theory 42: 39-44.

Konstan, D. 1994: 'Premarital Sex, Illegitimacy, and Male Anxiety in Menander and Athens', in A. L. Boegehold \& A.C. Scafuro (eds), Athenian Identity and Civic Ideology, 217-235. Baltimore: The Johns Hopkins University Press.

Laiou, A. E. (ed.) 1993: Consent and Coercion to Sex and Marriage in Ancient and Medieval Societies. Washington D.C.: Dumbarton Oaks Research Library \& Collection.

Lamb, W. R. M. 1930: Lysias. Cambridge: Harvard University Press.

Lape, S. 2001: 'Democratic Ideology and the Poetics of Rape in Menandrian Comedy', CA 20(1): 79-119.

Lefkowitz, M. 1986: Women in Greek Myth. London: Duckworth.

Lefkowitz, M. 1993: 'Seduction and Rape in Greek Myth', in Laiou (ed.), 17-37.

MacDowell, D. M. 1976: 'Hybris in Athens', G\&R 23(1): 14-31.

MacDowell, D. M. 1989: 'The Oikos in Athenian Law', CQ 39(1): 10-21.

Masterson, M. Rabinowitz N. S. \& Robson, J. (eds) 2015: Sex in Antiquity: Exploring Gender and Sexuality in the Ancient World. London \& New York: Routledge.

Mayor, A. 2014: The Amazons: Lives \& Legends of Warrior Women across the Ancient World. Princeton \& Oxford: Princeton University Press.

Murray, A. T. 1939: Demosthenes. Cambridge: Harvard University Press.

Ogden, D. 1997: 'Rape, Adultery and Protection of Bloodlines in Classical Athens', in Deacy \& Pierce (eds), 25-41.

Omitowoju, R. 2002: Rape and the Politics of Consent in Classical Athens. Cambridge: Cambridge University Press.

O’Neil, E. Jr, 1938: Aristophanes. Birds. - The Complete Greek Drama, Vol. II. New York: Random House. 
Pabdug, R. A. 1999: 'Sexual Matters: on Conceptualizing Sexuality in History', in R. G. Parker \& P. Aggleton (eds), Culture, Society and Sexuality: A Reader, 1528. London: Routledge.

Pierce, K. F. 1997: 'The Portrayal of Rape in New Comedy', in Deacy \& Pierce (eds), 163-184.

Pomeroy, S. B. 1975: Goddesses, Whores, Wives, and Slaves. New York: Schocken Books.

Porter, R. 1986: 'Rape-does it have a Historical Meaning?', in S. Tomaselli \& R. Porter (eds), Rape: An Historical and Cultural Enquiry, 216-237. Oxford: Blackwell.

Potter, R. 1939: Euripides, in W. J. Oates \& E. O’Neil, E. (eds), The Complete Greek Drama in 2 vols, 1 Ion (lines 436-451, 859-869, 874-906). New York: Random House.

Pretorius, J. 2017: 'Rape and Infidelity: threats to the Athenian Пo'des and Oixos', Fundamina (Pretoria), 23(2): 39-61.

Rabinowitz, N. S. 2011: 'Greek Tragedy: A Rape Culture?’, EuGeStA 1: 1-21.

Roy, J. 1999: 'Polis and Oikos in Classical Athens', G\&R 46(1): 1-18.

Scafuro, A. C. 1990: 'Discourses of Sexual Violation in Mythic Accounts and Tragic Versions of The Girl's Tragedy', Differences: A Journal of Feminist Cultural Studies 2(1): 136-159.

Scafuro, A. C. 2017: 'Greek Sexual Offences and Their Remedies: Honor and the Primacy of Family', in I. Peled (ed.), Structures of Power: Law and Gender Across the Ancient Near East and Beyond, 41- 59. Chicago: The Oriental Institute of the University of Chicago.

Sommerstein, A. H. (ed.) 2014: 'Menander: Samia (the Woman from Samos)', in Cambridge Greek and Latin Classics, 1-36. Cambridge: Cambridge University Press.

Symons, J. A. 2010: A Problem in Greek Ethics: Being an Inquiry into the Phenomenon of Sexual Inversion, Addressed especially to Medical Psychologists and Jurists. Project Gutenberg.

Walcot, P. 1978: 'Herodotus on Rape', Arethusa 11(1): 137-147.

Wohl, V. J. 1993: 'Standing by the Stathmos: The Creation of Sexual Ideology in the Odyssey', Arethusa 26(1): 19-50 